\title{
Implementation of Visuals Arts (Fined and Applied Arts) as Vocational Programmes in Tertiary Institutions: Problems and Prospects
}

\author{
Ogboji, Bernadine Anene ${ }^{1}$, Onuoha, Chijioke ${ }^{2} \&$ Ibenegbu, Christopher ${ }^{1}$ \\ ${ }^{1}$ Department of Arts Education, University of Nigeria, Nsukka, Nigeria \\ ${ }^{2}$ Department of Fine and Applied Arts, University of Nigeria, Nsukka, Nigeria \\ Correspondence: Janet Igbo, Department of Educational Foundations, University of Nigeria, Nsukka, Nigeria. \\ Tel: 23-803-746-9921. E-mail: janetigbo@yahoo.com
}

Received: July 6, 2016

Accepted: July 18, 2016

Online Published: November 16, 2016

doi:10.5539/res.v8n4p131

URL: http://dx.doi.org/10.5539/res.v8n4p131

\begin{abstract}
Over the years, Nigeria and indeed world leaders have been battling to combat the raging poverty and unemployment rates. Although vocational education has been identified as a panacea to these, significant studies reporting obstacles to the implementation of visuals arts as vocational education programs in tertiary institutions have remained grossly insufficient. This is the issues addressed in the study. Survey research design was adopted while 200 purposively selected art education and vocational education respondents from the University of Nigeria, Nsukka, provided participated in the study. Among others, that the respondents agreed that the problems facing the implementation of visual art in tertiary institutions as a vocational education program range from poor awareness to lack of parental support. Further studies examine from students' perceptive, on how best to implement visuals arts as vocational education programs are recommended.
\end{abstract}

Keywords: implement, problems tertiary institutions visuals arts, vocational programs

\section{Introduction}

Visual arts is a very broad aspect of art that includes areas like photography, painting, ceramics, drawing, filmmaking, craft, architecture, sculpture, printmaking, design, crafts, video, among others forms of aesthetics. These arts forms are very essential because people can hardly do without them. For example, those who have built houses need them painted, those who have occasions (e.g., weddings, funerals, naming ceremonies, birthday parties etc.) need to keep memories of such events alive through photographs and video coverage. The instances are many and as such, provide insight into centrality of visual arts to any society. Maryland State Department of Education (2012) define visual arts as all forms of creative and expressive production in material and media resulting in architecture, painting, sculpture, photography, craft, ceramics, printing, and applied design. Hagtvedt, H., Hagtvedt, R. and Patrick (2008) noted that visual arts are complex stimuli that provoke emotions. McCarthy, Ondaatje, Brooks and Szántó (2005) classified visual arts into embedded art such as design work embedded, and collectibles and crafts such as photography, painting, and sculpture. Commenting further, McCarthy et al. write:

These different categories of objects differ in their quality, in who consumes and produces them, and in the nature of the markets (size, price levels, and organizations) in which they are sold and displayed. Drawing bright lines between these different categories of visual arts objects is somewhat arbitrary, but we assert that understanding the structural differences is central to understanding the present state of the visual arts (p.xiv).

The interest of the current study from the assertion of McCarthy et al. above is not just about the definition of visual arts or what constitutes it, but the mention of producers and consumers of visual arts. What this means therefore is that visual arts, when properly handled as vocational program, could serve as a means of income and eventually, reduce the poverty rate and unemployment currently ravaging the Nigerian state.

It is an open secret that poverty rate in Nigeria is alarming. The World Bank (2014) world development indicators showed that $63.1 \%$ of Nigerian population lives below $\$ 1.25$ a day while $83.1 \%$ live below $\$ 2$ a day. 
What this suggests is that efforts aimed at reducing the poverty rate in Nigeria are encouraged. One of the ways of reducing poverty is through job creation. Unfortunately, unemployment rate in Nigeria is on the increase. The National Bureau of Statistics (NBS, 2016) defines unemployment as persons (aged 15-64) who are available for work, actively seeking for work but are without work. NBS also defined employment as a person who is engaged in the production of goods and services, thereby contributing to the Gross Domestic Product (GDP) in a legitimate manner. A survey by the National Bureau of Statistics (2016) showed that the working age population increased from 104.3 million in third quarter of 5015 to 105.02 million in fourth quarter of the same year. This represents a $0.68 \%$ increase over the previous quarter and a $3.2 \%$ increase when compared to fourth quarter of 2014. Also, the number of unemployed in the labor force increased by 518,102 persons, leading to an increase in the national unemployment rate to $10.4 \%$ in fourth quarter of 2015 from $9.9 \%$ in third quarter of the same year. This sad reality suggests the need to introduce more vocational education programs in Nigerian tertiary institutions (example colleges of education, polytechnics, monotechnics and universities) to make graduates self-dependent after graduation. Mshelia and Abbas (2012) corroborated that vocational education is a tool of poverty reduction by providing people with the skills and knowledge to raise their output and generate income.

Vocational education training provides learners with skills that develop craftsmanship as well as other practical problem solving approaches. Kotsikis (2007) holds that vocational education is aimed at the acquisition of qualifications related to a certain profession, art or employment or that provides the necessary training and the appropriate skills as well as technical knowledge. Efstratoglou and Nikolopoulou (2011) added that vocational education demands of specialties, as they are formed by the structural characteristics of each county's economy. The submission of Efstratoglou and Nikolopoulou suggest that vocational education programs regarding visual arts in Nigerian tertiary institutions must be structured such that consideration is given to the economic features of the Nigerian state. Oguejiofor and Ezeabasili (2014) noted that some researchers often refer to the twin concepts "Vocational-technical education" to mean education of skills or skill acquisition. The Nigerian National Policy on Education (2004) defines technical and vocational education as a comprehensive term referring to those aspects of the educational process involving in addition to general education, the study of technologies and related science and the acquisition of practical skills, attitudes, understanding and knowledge relating to occupation in various sectors of economic and social life. Going by the discourse so far, it can be said that scholars are in agreement that vocational education generally equips people with skills that will make them useful to themselves and the society. Umunadi (2013) corroborates that vocational education, if properly planned and implemented, could serve as an empowerment tool. In this light, Nwachukwu (2001) noted that in the planning and implementation of vocational education programs, the following should be taken into consideration:

First, the vocational and technical education curriculum must be in harmony. What this means is that such a curriculum should not be alien to the learners. The content of the curriculum must contain contemporary issues with local examples that the learners can easily identify. It will be very difficult for learners to cope with contents that are not familiar or that do not contain current issues. There are many contemporary issues, that when eloquently expressed in the contents of vocational education programs could stir and sustain learners' interest. For example, in the case of visual arts, it will be appropriate to provide learners with benefits in visual arts business such as photography, designing etc. An insight into the growing number of graduates unemployment in Nigeria could also be adequate.

In the second place, Nwanchukwu noted that learners must express readiness to receive what is taught. This is largely because certain factors significantly correlate readiness to learn. These factors, according to Uununadi (2013), are age, family background, nutritional status, fatigue or lack of it. Others are belief and attitudes of learners. Based on this premise, it can be argued that the effective teaching and learning will depend on the smartness of the teacher to identify these factors. For example, when a teacher understands that children from rich homes are less likely to pay attention to vocational programs than those from poor homes, such a teacher will tailor his/her teaching in such a way as to capture the attention of both children. The same thing is applicable to males and females as males, especially given the patriarchal system in Nigeria, are more likely to pay attention to vocational education programs than females. This is because, in Nigeria, and indeed Africa, the males are made to understand that as the head of the family, they must work hard while the females are made to understand that they do not necessarily need to work hard because a man will, in the final analysis, marry them and take over their responsibilities. What this means is that, teachers who want to succeed in teaching vocational education programs must devise ways of igniting and sustaining the interest of both sexes.

Thirdly, Nwanchukwu added that learning experiences must create a convivial atmosphere for the learners to engage in critical thinking that will ultimately lead to the generating of ideas. Thinking is very essential in 
vocational education programs because it is the process through which solutions are provide to problems. Nwachukwu (2001) averred that thinking is the entire process of addressing problems. Okolocha (2012) suggested ways of implementing vocational education programs thus: Putting in place workable policies and strategies; advocating vocational technical education as a key element in the education industry; learning in authentic and real-world environments; encouraging continuity in vocational technical education and training; putting in place coherent guidance and counselling system which will help to put students in proper career path; encouraging the development and usage of qualified trainers; creating awareness through image building, vocational attractiveness and participation in vocational technical education in Nigeria Setting up ambitious and realistic goals that will enable Nigeria to be the most competitive and knowledge based economy by the year 2020; creating and sensitizing the Nigerian populace on the need and vision of vocational technical education; maintaining approved school age and exit in order to pave way for physical and mental maturity required for the acquisition of vocational skills; encouraging investment in quality vocational technical education system; tackling the issues of insufficient and lack of up-to-date data for assessment of progress in vocational technical education; adopting stringent measures for proper and efficient execution of policies regarding VT; adopting uniform standard and certification in vocational technical education at all levels.

Although vocational education programs are generally considered as effective tools for economic empowerment and job creation, its implementation in Nigeria has been limited by several factors. Akhuemonkhan, Raim and Dada (2014) in a study purposively sampled 150 respondents from Yaba College of Technology, Federal College of Education (Technical), Lagos State Polytechnic and Federal Science and Technical College found that lack of quality assurance has impacted negatively on the implementation of vocational education programs within the study area. This study is relevant to the current one because it provides empirical data in the study of the obstacles against effective implementation of vocational education in Nigeria. Also, Lilly and Efajemue (2011) did a study to find out the challenge of vocational education in Rivers state Nigeria. The population of the study was vocational students at tertiary level in Rivers state. A sample of 288 was derived from vocational National College of Education (NCE) and post NCE students in proportion of 150 and 138 respectively in two tertiary institutions in the state. Structured questionnaire was used to collect data. Simple percentages and chi-Square (X2) were used to analyze the data collected. The researchers found significant differences on the perception of problems such as poor planning, lack of political will, poor infrastructure and ineffective SIWES (Students Industrial Work Experience Scheme) in the implementation of vocational teacher trainee programs.

Although the literature on vocational education is enormous, significant attention has not been paid to its implementation vis-a-vis visual arts. Scholars have often investigated vocational education in general thus leaving a gap with regards to specificity. This reality has led to the emergence of the following posers-what are the problems facing the implementation of visual arts as a vocational education programs in tertiary institutions in Nigeria? How can visual arts best be implemented as a vocational education program? What prospects await the implementation of visuals arts education as a vocational program in Nigerian tertiary institutions?

\section{Methods}

Descriptive survey was used for this study. The design is usually deemed applicable when the aim of a study is to describe, explain or explore a phenomenon (Babbie, 2013). Therefore, hence this study sought to explore problems and prospects of implementation of visual arts as a vocational education program in tertiary institutions, survey was considered useful. The population of this study was all the arts education and vocational education staff of the University of Nigeria, Nsukka. It was very difficult to describe the population in figures because of the absence of a list containing all the staff. Efforts to get the list failed.

The researcher determined the sample size for this study through a purposive sampling means. Therefore, 200 respondents (100 each of art education and vocational education) were sampled to participate in the study. Copies of the questionnaire were administered to the respondents at their various offices between the hours of 8 am- $4 \mathrm{pm}$. The instrument was administered by the researcher personally to avoid too much cases of missing copies.

To determine the face validity of the instrument, its initial copies with purpose and research questions were given to two experts. One from Educational Foundations, and one from Sociology of Education, both from the University of Nigeria, Nsukka. They were specifically requested to assess the adequacy of the items in getting the required data, the quality of its language and the logicality of its arrangement. At the end, some items were removed, others restructured and new ones provided in their place. Their comments were strictly adhered to by the researcher to produce a final copy of the instrument. 
To determine the reliability of the questionnaire, it was trial tested on 20 respondents $(10$ art education respondents and 10 vocational respondents) from Enugu State University of Science and Technology (ESUT). Care should be taken that these respondents were considered appropriate for the trial testing because they possessed the same characteristics as those from the study area. Cronbach Alpha method was adopted to measure the consistency coefficient of the questionnaire. Cronbach Alpha was considered appropriate because it ensured the homogeneity of items on the sections.

The Cronbach Alpha values were .786 for Table 1, and .89 for Table 2. The results indicated that the various sections were reliable. The Statistical Package for Social Sciences (SPSS) was used in the analysis. In doing so, descriptive statistics and inferential statistics were used. Among descriptive statistics methods, mean and standard deviation were used to answer the research questions.

\section{Results}

Out of the 200 copies of the questionnaire administered, 196 (98\%) were returned and found useful. The result is hereby presented below:

Table 1. Mean and Standard deviation of respondents on the problems facing implementation of visual arts as vocational education program in tertiary institutions

\begin{tabular}{lcccc}
\hline & & Mean & SD & Remark \\
\hline $\mathbf{2}$ & Lack of awareness on the part of students & 3.5 & 0.35 & Accepted \\
& Poor commitment on the part of school management & 3.4 & 0.76 & \\
$\mathbf{3}$ & Poor counselling for students on the importance of visual arts & 3.5 & 0.67 & \\
$\mathbf{4}$ & an empowerment tool & 3.4 & 0.65 & \\
$\mathbf{5}$ & Lack of fund & 4 & 0.79 \\
$\mathbf{6}$ & Non-inclusion of visual arts as a vocational program in the & 3.1 & 0.54 & \\
$\mathbf{7}$ & curriculum of tertiary schools & 3.5 & 0.78 \\
$\mathbf{8}$ & Too much emphasizes on paper qualification & 3 & 0.67 & \\
\hline
\end{tabular}

Source: Field survey, 2015.

The result from the table above revealed that the respondents agreed that the problems facing the implementation of visual art in tertiary institutions as a vocational education programme range from poor awareness to lack of support from parents. This is because all the items presented in the table had mean scores of 3.0 and above, which is within the accepted bench mark. Table 2 shows how visual how visual arts can best be implemented in tertiary institutions.

Table 2. Mean and Standard deviation of respondents on the how to implement visual arts as vocational education program

\begin{tabular}{|c|c|c|c|c|}
\hline & & Mean & SD & Remark \\
\hline 1 & $\begin{array}{l}\text { Creating awareness to students on the importance of visual arts } \\
\text { as an empowerment tool }\end{array}$ & 3.2 & 0.34 & Accepted \\
\hline 2 & $\begin{array}{l}\text { Training and retraining of instructors on modern trends in visual } \\
\qquad \text { arts }\end{array}$ & 3.1 & 0.96 & \\
\hline 3 & $\begin{array}{c}\text { Counselling students on the importance of visual arts an } \\
\text { empowerment tool }\end{array}$ & 3.7 & 0.69 & \\
\hline 4 & Provision of fund & 3.2 & 0.67 & \\
\hline
\end{tabular}




\begin{tabular}{|c|c|c|c|c|}
\hline 5 & $\begin{array}{l}\text { Punishing students who do not indicate interest in visual arts } \\
\text { vocation }\end{array}$ & 2.9 & 0.89 & Rejected \\
\hline 6 & $\begin{array}{l}\text { Visual arts as a general and compulsory course for all students at } \\
\text { the tertiary level vocational programme in the curriculum of } \\
\text { tertiary schools }\end{array}$ & 3.7 & 0.59 & Accepted \\
\hline 7 & Less emphasises on paper qualification & 3.8 & 0.75 & \\
\hline 8 & Parental support children to engage in visual arts as a & 3.2 & 0.63 & \\
\hline
\end{tabular}

Source: Field survey, 2015.

The result from the table above revealed that the respondents agreed that to properly implement visual art as a vocational education programme in tertiary institutions, awareness must be created on its importance, there should be regular training and retraining of instructors to guide learners, periodic counselling should be carried out, fund should be made available to sponsor the programme, it should be included as a general and compulsory programme for all students, less emphasises should be placed on paper qualification while parents should also support their children and wards.

\section{Discussion of Findings}

The result of this study showed the existence of a myriad of obstacles against the implementation of visuals arts as vocational education programs in tertiary institutions in Nigeria. This findings run similar to that of Akhuemonkhan, Raim and Dada (2014) and Lilly and Efajemue (2011) who found that implementation of vocational education programs in tertiary institutions has suffered setbacks because of factors ranging from financing, to lack of interest, to lack of qualified instructors among others. The findings also suggest the way forward (e.g., creation of awareness, funding, counselling, less emphasizes on paper qualification etc.) on how to better implement visuals arts as vocational education programs in tertiary institutions. This finding has opened a new debate on approaches towards combating poverty and reducing the rising rate of unemployment in Nigeria. Each year, the existing tertiary institutions in Nigeria churn out graduates to join others already frustrated in the labour market. Duze (2010) cited in Temple (2014, p. 18) paints a gory picture of the situation thus:

University graduates in their millions, roam the streets searching for non-existing collar jobs. It has become increasingly difficult for school leavers from all levels and types of education (including vocational/technical/business education graduates) to transit from school to wage earning employment as hundreds of thousands of them are turned into the labour market at the end of every academic session, without a corresponding rise in paid jobs. It is no longer like the oil boom years of the seventies and eighties when automatic transition from school to employment was the case.

Visuals arts present a viable avenue through which graduates of tertiary institutions can become self-dependent. This is because of the existence of its different forms like ceramics, painting, film making, photography among others. Graduates can choose from among these many visuals arts forms become experts and eventually gain skill of it that can become a source of income. It is expected that school administrators and government agencies will find the result of this study useful in a bid to promote vocational education, reduce unemployment and empower graduates. Further studies determining obstacles against students' interest in visuals arts are encouraged. It is also recommended that subsequent studies should examine from students' perceptive, how best to implement visuals arts as vocational education programmes. Finally, it is recommended that all stake holders in the Nigerian project should form a synergy and ensure the full implementation of visuals arts as vocational education programs in Nigerian tertiary institutions.

\section{Acknowledges}

Am grateful to all those who participated in this study. I also thank all my colleagues who helped in proof reading this paper.

\section{References}

Akhuemonkhan, I., Raim, R., \& Dada, J. O. (2014). Impact of quality assurance on technical vocational education and training in Nigeria. Afro Asian Journal of Social Sciences, 5(5), 1-25.

Babbie, E. (2013). The practice of social research (13th ed.). US: Wadsworth. 
Efstratoglou, A., \& Nikolopoulou, B. (2011). Vocational Training as Educational Policy and as Policy for Employment and Labor Market. In M. Gravani (Ed.), Vocational Education and Training (pp. 27-52). Cyprus: Open University of Cyprus.

Federal Republic of Nigeria. (2004). National Policy on Education (4th ed.). Abuja: Federal Republic of Nigeria.

Hagtvedt, H., Hagtvedt, R., \& Patrick, V. (2008). The perception and evaluation of visual art. Empirical Studies of the Arts, 26(2), 197-218. http://dx.doi.org/10.2190/EM.26.2.d

Kotsikis, V. (2007). Educational administration and policy. Athens: Ellin.

Lilly, G., \& Efajemue, O. O. (2011). Problems of vocational teacher education in Rivers State, Nigeria. In Proceedings of the 2011 International Conference on Teaching, Learning and Change.

Maryland State Department of Education. (2012). Visual Arts Glossary. Retrieved from https://www.edutopia.org/pdfs/stw/edutopia-stw-bates-artsintegration-glossaryvisualarts.pdf

McCarthy, K. F., Ondaatje, E. H. B., \& Szántó, B. (2005). Research in the Arts. Arlington: Rand Corporation.

Mshelia, A. G., \& Abbas, L. (2012). Technical and vocational education: A means to self-employment and the realization of Nigeria vision. Journal of Research in Education and Society, 3(1), 64-69.

National Bureau of Statistics. (2016). Unemployment/under-employment report Q4 2015. Retrieved from http://www.nigerianstat.gov.ng/

Nwachukwu, C. E. (2001). Designing appropriate methodology in vocational and technical education in Nigeria. Nsukka: Fulladu Publishing.

Oguejiofor, S. C., \& Ezeabasili, A. C. C. (2014). Imperatives of vocational education and sustainable development in Nigeria. An International Multidisciplinary Journal, Ethiopia, 8(1), 42-52. http://dx.doi.org/10.4314/afrrev.v8i1.4

Okolocha, C. C. (2012). Vocational Technical Education in Nigeria: Challenges and the Way Forward. Business Management Dynamics, 2(6), 1-8.

Temple, S. (2014). Attitudes of secondary school students to entrepreneurship education in Nsukka education zone. Postgraduate project Submitted to the National Teachers Institute, Nsukka Study Centre for the award of postgraduate diploma in Education.

Umunadi, E. K. (2013). Functional vocational and technical education curriculum for sustainable youth empowerment in Nigeria. British Journal of Education, 1(1), 7-13.

World Bank. (2014). World development indicators. Retrieved From http://data.worldbank.org/sites/default/files/wdi-2014-book.pdf

\section{Copyrights}

Copyright for this article is retained by the author(s), with first publication rights granted to the journal.

This is an open-access article distributed under the terms and conditions of the Creative Commons Attribution license (http://creativecommons.org/licenses/by/4.0/). 